\title{
NOTAS
}

\section{Nuestro Homenaje a Alfonso Reyes}

$\mathrm{E}$ L origen de este Homenaje a Alfonso Rejes nació de una sugerencia que hice a los profesores Luis Leal y Alfredo A. Roggiano, quienes la acogieron con la mayor simpatía en la reunión celebrada por la Modern Language Association en diciembre de $\mathrm{r}_{96} 6_{3}$ en el Palmer House, Chicago. Decidimos alli invitar a otros dos estudiosos y admiradores de la obra del mexicano universal a que participaran en el programa de diciembre de I965 de la MLA: los doctores James Willis Robb y Angel Luis Morales. El profesor Roggiano expresó luego la feliz idea de recoger las ponencias en nuestra Revish Iberoamericana.

Cuando el 28 de diciembre de 1964 tuve el honor, en el SheratonAtlantic, Nueva York, de iniciar el acto honrando al Maestro Reyes, leí las brevisimas frases que copio:

Sólo declaro al comenzar que considero como un privilegio ha. blar en español y entender el mundo en español: lengua de sintesis y de integración histórica, donde se han juntado felizmente las formas de la razón occidental y la fluidez del espiritu oriental; ... (len. gua) capaz de la matemática como de la lírica; valiente en la cor. dura y en la locura...

Palabras son ésas de verdad y poesía, escritas por el maestro Alfonso Reyes, $y$ nada mejor que repetirlas en esta mañana en que dedicamos nues-

1 A. Reyes, Tentaimas y orientaciones (México, Nuevo Mundo, 1944); Pp. 197-198. 
tro homenaje a aquella egregia figura de alma mexicana, iberoamericana, helénica, renacentista, universal, que entró al seno del misterio hace exac. tamente cinco años, el 27 de diciembre de 1959, aunque siempre, lumbre inmortal, vigilará desde el cielo de América.

Nosotros expresamos nuestra gratitud a la vida misma por habernos permitido ver aquellos ojos de sabiduría, tan afanosos siempre en la $C a$. pillat alfonsina; por la lección cotidiana de aquella vida ejemplar, por la obra y el magisterio de Alfonso Reyes, uno, con Pedro Henríquez Ureña, de los dos más altos símbolos del humanismo iberoamericano en el siglo $\mathrm{xx}$.

No olvidaremos que, además de sus estudios de estética y literatura, el autor de Atenea politica nos legó un mensaje moral de eterna vigencia. "Hay que predicar, dijo - por encima de todas las disidencias teológicas en cuanto a la proyección sobrenatural de la vida humana-, algo como una religión terrestre, que nos despierte al sentido ético de nuestra misión natural". 2 Su concepto de cultura como tradición, cosmopolitismo, notmas, ideas y emociones, pone el acento en la conducta humana. Cree que sólo la democracia puede salvarnos. América es, para él, "una mayor posibilidad de elección de bien". 3 "para América no hay más raza que la raza humana"4 y "todos los pueblos son mestizos". 5 Retorna, con José Enrique Rodó, al tema de la profesión general, universal, del hombre; quiere, para ser leal a la tierra y al cielo, el equilibrio de los tres saberes de Max Scheler, y reafirma su fe profunda en la inteligencia americana, atenta a lo ecuménico y a lo autóctono.

Hontamos, pues, al hombre de letras, al humano y humanista, al que, en carta al filósofo Francisco Romero, habló de disciplina, asimilación $y$ su. peración, ${ }^{6}$ al poeta descrito en los versos que elogió Eugenio Florit: ${ }^{7}$

$$
\begin{aligned}
& \text {.. mano que sin saber ordena y tasa } \\
& \text { un ancho paraíso de armonia. }
\end{aligned}
$$

al ensayista, crítico y polígrafo; al Maestro que defendió y ejemplarizó el

2 Ibid., p. 221. Vid.: Manuel Olguín, "La filosofía social de Alfonso Reyes", Sexto Congreso del Institnto Internacional de Literatura Iberoamericand: Homenaje a Hidalgo, Diaz Mirón y Martí (México, Imprenta Universitaria, 1954), pp. 249-250.

3 Ibid., p. 137.

4 Ibid., p. 143.

5 Ibid., p. 200.

6 A. Reyes, Obras completas, XI (México, Fondo de Cultura Económica, 1960), p. 79.

2), p. 54 . 
decoro; a quien se esforzó en crear, para el hombre, una morada de jus. ticia, paz creadora, igualdad civil, libertad y belleza.

Subrayando la universalidad de espiritu de Alfonso Reyes nos reunimos, simbólicamente, hombres de diversas patrias, para traer esta ofrenda: un argentino, un mexicano, un norteamericano y dos antillanos.

José ferrer Canales

\section{Howard Universify}


